\title{
A borderline leprosy lesion on the palate: a case report
}

\author{
B MISHRA, A GIRDHAR, S HUSAIN \\ G N MALAVIYA \& B K GIRDHAR \\ Central JALMA Institute for Leprosy, Tajganj, AGRA-282 001, \\ India
}

Accepted for publication 9 June 1987

Summary A patient with borderline tuberculoid leprosy was found to have involvement of hard palate which was histologically compatible with borderline leprosy (BB) in reaction. The possible modes of involvement of palate are discussed.

\section{Introduction}

Infiltration of the tissues like palate, gums and nasal mucosa has often been reported in lepromatous cases. Oral involvement was found in $19 \%$ of the cases. ${ }^{1}$ Another study ${ }^{2}$ observed that $60 \%$ of the lepromatous cases had oral involvement, and others ${ }^{3}$ observed that $57 \%$ of the 40 lepromatous cases had oral affection. In nonlepromatous cases, the disease does not involve the mucous membrane and it seems that lesions in these patients, usually do not cross the mucocutaneous junction.

Recently we came across a patient of borderline leprosy having leprosy lesion on mucosa of hard palate. Because of the rarity of mucosal lesion in nonlepromatous patients the case is being reported.

\section{Case report}

A 45-year-old Hindu female attended the OPD with complaints of gradually appearing multiple analgesic erythematous patches all over the body during the previous five years. She had taken $100 \mathrm{mg}$ of DDS and $10 \mathrm{mg}$ of prednisolone daily for 4 weeks. She had also received a single dose of $600 \mathrm{mg}$ of rif ampicin at the initiation of the therapy.

On examination, she was found to have multiple, widespread, asymmetrical, raised, erythematous, oedematous, dry scaly lesions with well-defined margins. All the lesions were analgesic. Lesions were present on the face, trunk and extremities. None of the nerve trunks were thickened and there were no associated deformities. The skin smear report was as follows: on right ear negative, lesion on forehead negative, lesion on left leg positive (I+). Mitsuda reaction to lepromin was strongly positive $(+++)$. The patient was diagnosed as having borderline tuberculoid leprosy in reaction. 
On detailed examination a raised pinkish patch of about $2 \times 3 \mathrm{~cm}$ with 3 small ulcers, was noticed on the mucosa of hard palate on the left side of midline (Figure 1).

\section{Histopathology}

A biopsy specimen from the lesion on the left forearm shows skin with normal keratinization. The epidermis shows flattened rete pegs. The dermis is almost totally filled by a granuloma, composed of numerous macrophages. In some areas there is focalization and collection of epithelioid cells and poorly formed giant cells. Numerous lymphocytes and an almost equal number of plasma cells are seen throughout the granuloma, either scattered diffusely or forming cuffs around the focal collections. The nerves are replaced by epithelioid cell collections. Fite stain shows acid-fast bacilli in small groups within the macrophages (BI-3+). The picture is consistent with BT/BB leprosy.

A section through the palate shows dense granuloma covered by stratified squamous epithelium. The granuloma consisted mostly of macrophages, with a dense infiltration by lymphocytes. Several plasma cells are also seen. In areas there are focal collections of histiocytes and immature epithelioid cells with abundant eosinophillic cytoplasm. In this area infiltrating cells are mainly lymphocytes and hardly any plasma cells observed there. Fite stain shows diff usely scattered acid-fast bacilli (BI-3+). Bacilli were very rare in the focalized area. In view of a very large number of capillaries and some oedema the lesion could be in reaction. The histological picture is consistent with BB type of leprosy in reaction.

\section{Treatment and progress}

She was put on monthly pulsed rif ampicin $600 \mathrm{mg}$, dapsone $100 \mathrm{mg}$ and prednisolone $5 \mathrm{mg}$ daily. At the end of 4 months the lesions on the skin and also the palate lesion showed evidence of regression. The ulcers on the palate lesion healed, but the pinkish raised lesion was still evident. Unf ortunately the patient disappeared subsequently and further follow up has not been possible.

\section{Discussion}

Presence of borderline lesion on palate in a case of BT/BB leprosy is an odd presentation and to the best of our knowledge, has not been reported so far.

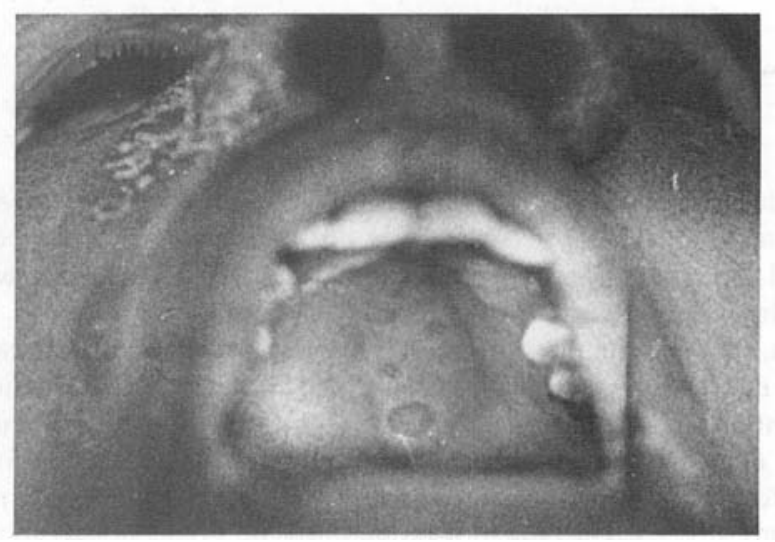

Figure 1. Lesion on palate showing ulcers. 

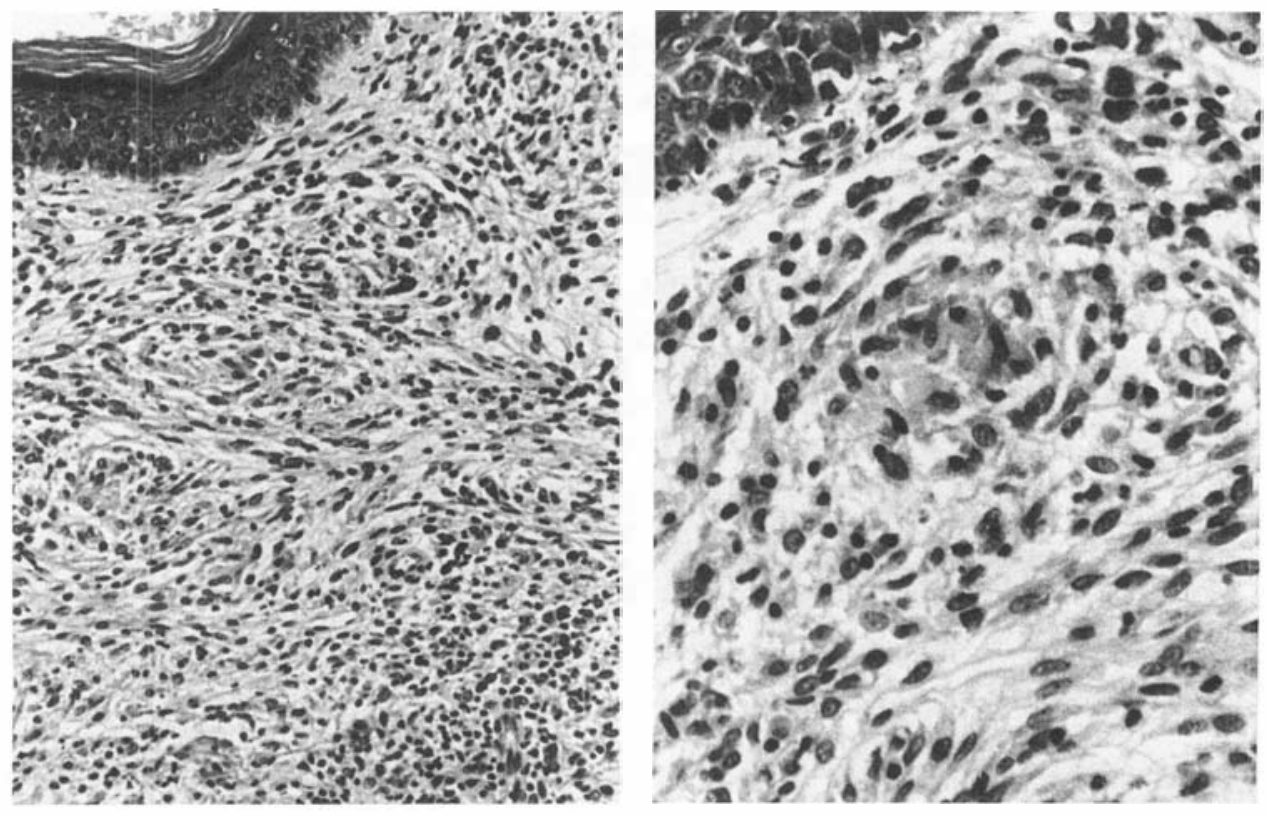

Figure 2. Section through skin lesion showing extensive granuloma with epithelioid cells and a large number of lymphocytes $(\mathrm{H} \& \mathrm{E}$ original $\times 200)$.

Figure 3. High power view of granuloma of skin showing epithelioid cell focus $(\mathrm{H} \& \mathrm{E}$ original $\times 400)$.

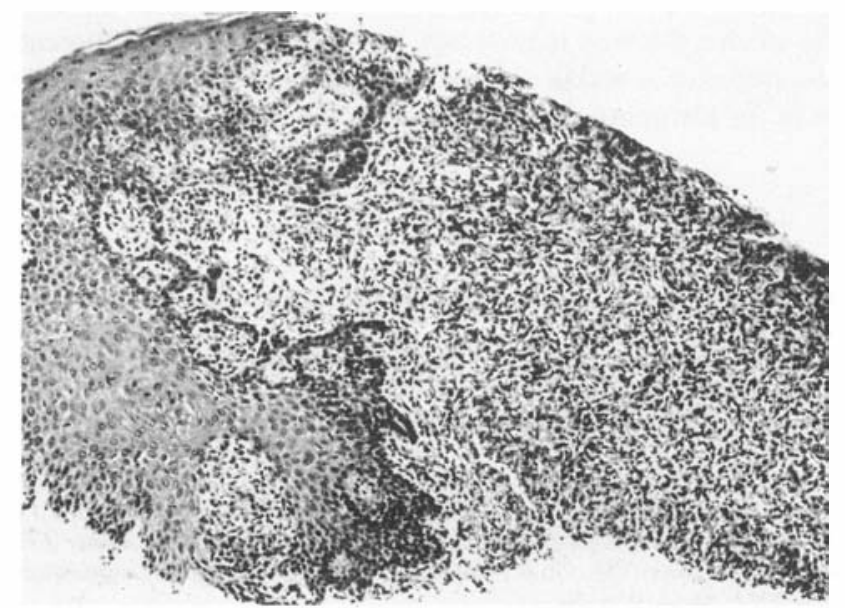

Figure 4. Photomicrograph of palate lesion showing extensive granuloma in the subepithelial tissue (H \& E original $\times 100)$.

In the past various theories have been put forward to account for the site of selection and localization of nonlepromatous lesions. The possibility of a lesion appearing at the site of initial inoculation was suggested earlier. ${ }^{4}$ Case reports regarding lesion at the site of initial inoculation support this view. ${ }^{5-7}$ In the present report, though the lesion was noticed at the time of the first examination, because of its asymptomatic and insidious nature, it was difficult to ascertain whether it w/as the first lesion or appeared after the skin lesions. 


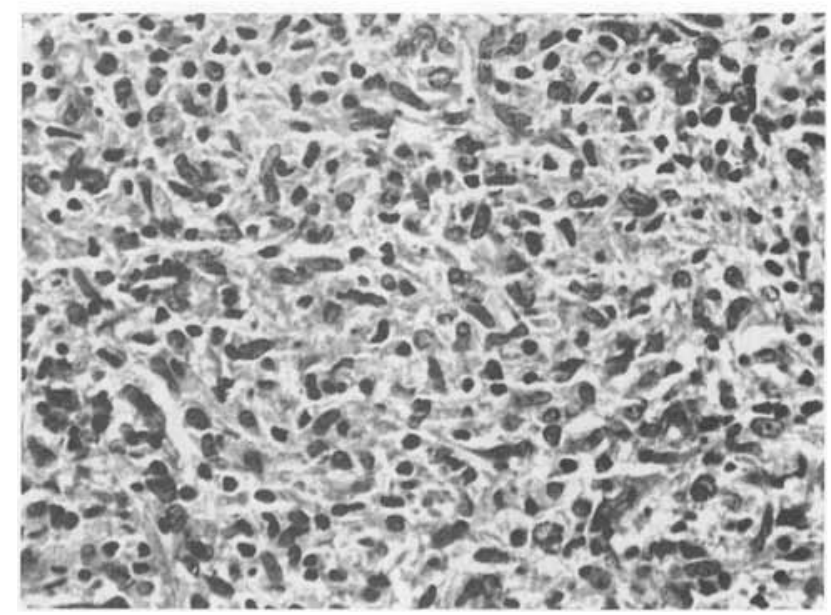

Figure 5. High power view of palate lesion, showing a granuloma composed of histiocytes, plasma cells and lymphocytes $(\mathrm{H} \& \mathrm{E}$ original $\times 400)$.

Lower temperature on both the surf aces of the palate, might have contributed to the localization of the lesion at this site, as it has been suggested that $M$. leprae has predilection for cooler areas of the body. ${ }^{89}$ It is possible that in the present case the palate lesion occurred by haematogenous spread of the bacteria. Bacteraemia has been shown in 8 out of the 11 investigated TT/BT cases. ${ }^{10}$ As such haematogenous spread of the infection in TT/BT cases cannot be ruled out.

It is interesting to note that the palate lesion showed a histological picture at a lower level of immunological scale. Such a diversity in histology has been reported in different skin lesions of the same patient. ${ }^{11}$ Also a dichotomy in skin and nerve lesions has been observed..$^{12}$ One could therefore expect a divergence in the histopathology of lesion on the mucosa compared to one on the skin.

\section{References}

${ }^{1}$ Bechelli LM, Berti A. Lesoes Leproticas de mucosa buccal. Estudo clinico. Rev Brasil Leprol, 1939; 7: 187. (Quoted by Girdhar BK and Desikan KV.)

2 Lighterman I, Wantabe Y, Hikada T. Leprosy of oral cavity and adenexa. Oral Surg, 1962; 15: 1178. (Quoted by Girdhar BK and Desikan KV.)

${ }^{3}$ Girdhar BK, Desikan KV. A clinical study of mouth in untreated lepromatous patients. Lepr Rev, 1979; 50: $25-35$.

${ }^{4}$ Rogers L, Muir E. Primary infection. Leprosy. Bristol: John Wright and Sons Ltd, 1925; 167-72.

${ }^{5}$ Marchoux C. A case of leprosy due to accidental inoculation of Hansen bacilli. Int J Lepr, 1934; 2: 1-6.

${ }^{6}$ Porritt RJ, Olsen RE. Two simultaneous cases of leprosy developing in tattoo. Amer J Path 1947; 23: 805-17.

${ }^{7}$ Gupta CM, Tutakne MA, Tiwari VD, Chakraborty N. Inoculation leprosy subsequent to dogbite. A case report. Ind J Lepr 1984; 56: 4, 919-20.

${ }^{8}$ Hastings RC, Brand PW, Mansfield RF, Ebner JD. Bacterial density in the skin in lepromatous leprosy as related to temperature. Lepr Rev, 1968; 39: 71-4.

${ }^{9}$ Girdhar BK, McDougall, A C. The morphology of bacilli at different levels of the dermal infiltrate in lepromatous leprosy. Int J Lepr, 1982; 50: 4, 477-9.

${ }^{10}$ Raval SN, Sengupta U, Ramu G, Prabhune PV, Desikan KV. Study of continuous bacillaemia in borderline and lepromatous type of leprosy. Lepr India, 1982; 54: 4, 623-33.

11 Ganapati R, Desikan KV. Simultaneous occurrence of lesions of different types of leprosy in a patient. A case report. Lepr India, 1974; 46: 3, 148-51.

12 Srinivasan H, Rao KS, Iyer CGS. Discrepancy in the histopathological features of leprosy lesion in the skin and peripheral nerve. Report of a preliminary study. Lepr India, 1982; 54: 2, 275-82. 